\title{
"Venerable, Architectural, and Inconvenient": Rented Spaces in The Mystery of Edwin Drood
}

\author{
Ushashi Dasgupta, University of Oxford
}

When the enigmatic Dick Datchery arrives in Cloisterham in the fifth part of The Mystery of Edwin Drood, he asks the waiter at the Crozier Hotel where he might find a "fair lodging for a single buffer." "Something old is what I should prefer," he says, "something odd and out of the way; something venerable, architectural, and inconvenient [...] anything Cathedraly, now" (202-3; ch. 18). In his whimsy, Datchery lights upon a cluster of adjectives that could easily describe the novel he inhabits. As the Inimitable's final work, Edwin Drood is "venerable:" we seek, or indeed demand, evidence of Dickens's creative maturity among its pages. But it is also an "odd" and exhilaratingly "inconvenient" novel, unfinished at Dickens's death, pushed "out of the way" in frustration by those seeking categorical answers to the questions it raises. Finally, it is conspicuously "architectural," with a profusion of strange spaces and insights into the complexities of the nineteenth-century property market.

This essay puts forward three perspectives on space in the novel. ${ }^{1} \mathrm{I}$ begin by exploring Dickens's use of rented spaces to push Edwin Drood's mystery plot forward; lodgings and hotels perform a narrative function in his embryonic detective story. In the second section, I move away from literary form to suggest that he sets up an intrinsic relationship between space and feeling. His scenes in London's Staple Inn, in particular, are a profound meditation on living alone and loneliness and show him to be a subtler student of the emotions than he might get credit for. The final section considers the ways in which the novel's politics are articulated through space. Throughout, I draw upon the ideas of a range of theorists, because Dickens's own observations about the world around him are instinctive and varied; while twentieth-century thinkers may have picked up on similar ideas, developing them into sustained philosophical frameworks, what Dickens's fiction delivers is a set of provocative starting-points.

Embedded in Datchery's remark is an implicit parody of property advertising, which traded on rather different attributes to those he mentions. In notices from August 1870 - the same month the number was published - lodgings are promoted for their convenience, salubriousness and location: for example, "BOARD and RESIDENCE.-A lady, residing in a pleasant and healthy locality in the west-end of London, desires to meet with two or three Christian LADIES to SHARE her HOME..."2 The consumers and peddlers of domestic space seem to be passive, requesting and offering the same thing, unable to communicate what they

\footnotetext{
${ }^{1}$ On the "spatial turn" in cultural studies, see Isobel Armstrong, "Theories of Space and the NineteenthCentury Novel" (2003) and Robert T. Tally Jr., Spatiality (2013). An early version of this article was presented at "The Mystery of Edwin Drood: Solutions and Resolutions." I would like to thank the organizers, and everyone who attended, for their feedback.

2 The Times 1 August 1870 p. 13.
} 
seek as individuals. In his pursuit of "venerable, architectural, and inconvenient" lodgings, Datchery consciously rejects the tenets of desirable space perpetuated by house agents, landladies and unquestioning tenants; instead, he suggests that homeliness can be found and made elsewhere. These examples complicate our understanding of "topophilia" or "felicitous space," most extensively theorized by Gaston Bachelard and Yi-Fu Tuan; while Bachelard and Tuan describe the "affective bond between people and place or setting" as something private and even spiritual, Dickens suggests it is also shaped by contemporary market forces (Bachelard xxxvxxxvi; Tuan 4). As this essay shows, one of the major impulses in Edwin Drood is to hold up middle-class domestic ideology to sustained scrutiny, complicating tidy assumptions about Dickens's role in perpetuating such values.

Datchery finds sufficiently "Cathedraly" apartments at Mrs. Tope's; they are dark, close, "of no describable shape" and "as quaintly inconvenient as he could desire" (205; ch. 18). No matter how high the spires of the Cathedral loom, Edwin Drood is insistently drawn to other landmarks; here, a landlady's window-bill can be a "Cloisterham Institution" (203; ch. 18). Dickens presents a universe where tenancy - which combines economic transaction, legal agreement and personal relationship - has a real impact upon narrative and psychological development, plot and character. The novel sees him at his most spatially aware.

\section{Hybrid Hotels, Hybrid Fictions}

Tenancy was an unavoidable element of both urban and rural experience in the period. In 1873, four-fifths of the land in the country was owned by 7,000 landowners; of these, there were only 202 freeholders with major estates. ${ }^{3}$ While vast numbers of people leased entire houses, Henry Morley, one of the staff writers for Household Words and All the Year Round, estimated in 1855 that three-quarters of London households practised "lodging-letting [...] the black art of the nineteenth century" (183). To take lodgings was to rent rooms from a landlord or landlady who continued to live on the premises, and who provided a negotiable number of domestic services. With its emphasis on intimacy, security and the separation of the public and private spheres, the version of home celebrated by the champions of a certain kind of domestic ideology was largely a mirage. ${ }^{4}$ Dickens, a tenant for much of his life, was drawn to more complex models of the home and to rented spaces in particular. Of course, rented spaces could, and can, make viable and comfortable homes; nonetheless, renting involves a reassessment of the way home works, and Dickens was involved in this process of appraisal. Though he was by this stage ensconced in

\footnotetext{
${ }^{3}$ These figures come from FML Thompson's account of the New Domesday Survey in English Landed Society in the Nineteenth Century (1963), 27. See also Sharon Marcus, Apartment Stories (1999), 101-16.

${ }^{4}$ For discussions of Dickens and domestic ideology that also challenge this view, see Catherine Waters, Dickens and the Politics of the Family (1997), Karen Chase and Michael Levenson, The Spectacle of Intimacy (2000) and Holly Furneaux, Queer Dickens (2009).
} 
Gad's Hill, the "little Kentish freehold" he owned outright, Edwin Drood reveals an imagination still gripped by tenancy (Letters 8: 598). It is the apotheosis of a career that continually circled around this theme.

Dickens was not content to describe how people lived or to chart the various historical shifts that encouraged people to live as they did. Instead, he explored the ways in which particular modes of dwelling could, in becoming prominent, have a discernible impact on the range of narratives available to him. In Edwin Drood, then, he both anticipates and confirms an argument made by Franco Moretti: that "each space determines, or at least encourages, its own kind of story." "In modern European novels," Moretti suggests, "what happens depends a lot on where it happens" $(34,38,46,70)$. Rented spaces serve as narrative mechanisms in this mystery story. As the novel never ran its course, we cannot be entirely sure about the kind of work its spaces are meant to perform; nevertheless, the extant chapters offer plenty of clues pointing to their function in the crime and its solution. It is productive, then, to move beyond the automatic questions of "whodunit," "whydunit" or "howdunit," not least because the answers seem fairly evident in Edwin Drood. Instead, it is worth considering where the mystery may have played out and to ask which of these settings - from the Travelers' Twopenny, to Staple Inn - would have been significant. It is futile to ask which was the cause and which the effect - whether the increasing centrality of rented space in nineteenth-century domestic life pushed Dickens towards detection, or whether a desire to construct a detective plot turned his attention to rented spaces. It is also too extreme to suggest that there would be no detective plot without tenancy; Dickens was not dependent upon space for the license to write. Nonetheless, shifting our critical focus to questions of location reveals the extent to which space is anything but a passive receptacle, a backdrop or an abstract concept in nineteenth-century fiction.

In "On Duty With Inspector Field," Dickens recounts a night-time journey through London's most notorious slums. Field takes Dickens to a series of "low" or "common" lodginghouses; defined by legislators as establishments where lodgers either paid for beds by the night or were housed in a single room with other families, they received a huge amount of attention from politicians, philanthropists and members of the public in the 1840s and 1850s. "Inspector Field" is a sobering piece of social commentary which adopts, then casts off, various literary registers; our abiding sense is that the spaces it attempts to describe kill narratives. Sharon Marcus identifies a similar tendency in most writing about these spaces: "Urban observers singled out the ills of the lodging house for exhaustive description - and marked lodging houses as the cause of descriptive exhaustion. Almost all urban observers spoke of lodging houses as unspeakable" (107). At best, low lodging-houses were painted as sites of lost potential; at worst, they were shown to breed and harbor criminals.

\footnotetext{
${ }^{5}$ On low lodging-houses, see Tom Crook, “Accommodating the Outcast” (2002).
} 
At first, Edwin Drood seems to offer the same subdued argument about low lodginghouses with its depiction of the Travelers' Twopenny, a "wretched place" in Gas Works Garden. Made of wood, this "crazy" structure lacks the soundness of stone; with its "two low stories," it is squat; its "stamped-out garden" is a physical reminder of the sheer density of footfall - the relentless coming and going of anonymous transients. Its "lattice-work porch" and "rustic fence" are a sad testament to architectural degeneration; the Twopenny retains "the semblance of an inn," and these hints of old-world hospitality serve to make its shortcomings all the starker. In labeling it a "house all warped and distorted, like the morals of the travellers," Dickens rearticulates the ideas of certain mid-century commentators (such as Lord Ashley) and anticipates the fatalism of late-century literary naturalists (such as Gissing): the belief that circumstances were inescapable and formative, that certain living conditions encouraged antisocial behavior and that people shaped or scarred the spaces they lived in (50; ch. 5). The Twopenny, tucked away in a cathedral city, may not fall under the gaze of the usual "urban observers" Marcus mentions, but it is still a crucible for immorality and criminality. Its very existence, meanwhile, points to a wider institutional villainy, indicting a social system that allows the poor to dwell in this way.

It is in the figure of the "Deputy" that Dickens gives the clearest hints of progression. Both "Inspector Field" and Edwin Drood feature Deputies - a standard title given to the managers or attendants in low lodging-houses - but this is where the similarities end. In the article, one Deputy leads Field and Dickens along with a "flaring candle in [a] blacking-bottle;" another is a young girl, who "shows the way up a heavy broad old staircase" (Journalism 2: 364-66). Ushering the writer - and, by extension, the reader - into their dark world, Deputies are guides and gatekeepers rather than characters in their own right. In Edwin Drood, however, Dickens has the elbow-room to expand upon these references. Drood's Deputy is far more distinct and is granted a clear narrative purpose; he does not simply exist to open the door to the low lodging-house and urge horrified readers into meaningful social action. In Philippe Hamon's study of narration and description, description appears to be "supplementary to the narrative;" for Hamon, the introduction of certain characters acts as "plausible padding," whose "function is above all that of avoiding gaps between description and narration, of filling in the chinks in the narrative by making the interruptions possible" $(147,150,156-57)$. Drood's Deputy transcends this function; Dickens does not create him in order to justify polemical descriptions of poor housing. Instead, he is a demonic urchin, befriended by Datchery, enlisted as a spy in the Twopenny and commissioned to pass on invaluable information about Princess Puffer, who is lodging there for some nights. It is tantalizing to speculate what would have happened to and because of the Twopenny, had the novel been finished. Perhaps Deputy would have outgrown his title. Nominally a second-in-command or understudy, it is likely that he would have taken center stage in this novel's mystery plot, contributing his unique talents to the resolution of a middle-class crime. 
Datchery, who knows how to channel Deputy's devilish energy in the low lodginghouse, also seems to manipulate his own living arrangements to his advantage. Mrs. Tope's longneglected apartments to let receive a considerable amount of attention. Lodging is a convenient method for a detective to wring intelligence out of locals; at Mrs. Tope's, Datchery is Jasper's neighbor. Could this landlady - for whom Jasper provides a character reference, vouching for her respectability - have seen something to tarnish Jasper's own character? After all, fictional landladies trade in secrets. Because their day-to-day business gives them access to private information, it is not difficult to imagine a landlady's observations and idle chatter turning into testimony. Such a conjecture can only ever be a stab in the dark; nevertheless, Mrs. Tope's apartments hold a special place in Dickens's oeuvre. In the last scene Dickens wrote before his death, Datchery sits down to breakfast in his lodgings:

Mrs. Tope's care has spread a very neat, clean breakfast ready for her lodger. Before sitting down to it, he opens his corner-cupboard door; takes his bit of chalk from its shelf; adds one thick line to the score, extending from the top of the cupboard-door to the bottom; and then falls to with an appetite (272; ch. 23).

Dickens's inadvertent last word is to praise the figure of the landlady and the cozy domesticity that may be found in lodgings. He also makes a final broad suggestion about a tenant's daily negotiations between taking agency - on the one hand - and confronting his eventual effacement - on the other. Datchery is a lodger inscribing the inside of his cupboard-door with a language only he can read; with this spatial practice, he claims stubborn ownership over his rooms, even though they ultimately belong to someone else. Though a rental agreement restricts a tenant's movement and behavior in both overt and insidious ways, it is this kind of small, everyday action that allows him to make a mark and create the space afresh. Admittedly, Datchery makes his mark with chalk - a reminder that the presence of individual tenants will only ever be smoothed away in the end. At the same time, with a glimpse of the detective at work, Dickens offers a minor enigma to close the monthly part.

Cloisterham is a fragmented world, unable to escape the vicissitudes of the property market. Just as the probable detective in the case finds himself to be a tenant, so, too, the presumed culprit: when Jasper travels to London in the last existing chapter, he takes a room in a "hybrid hotel in a little square behind Aldersgate Street." It is one of many new establishments available to those traveling by train:

It is a hotel, boarding-house, or lodging-house, at its visitor's option. It announces itself as a novel enterprise in the new Railway Advertisers timidly beginning to spring up [...] From these and similar premises, many true Britons in the lowest spirits deduce that the times are levelling times (256; ch. 23). 
Dickens is commenting on the increasingly splintered nature of domestic space in the city, the impact of technological progress upon mobility and the soullessness of large-scale ventures in the hospitality industry. As London modernizes, space begins to divide to meet the demands of the increasingly exacting consumer. This, Dickens suggests, is not a positive development, perhaps because it encourages complacency: it quells the need for people to adapt to the spaces around them. Instead of making do or making adjustments of their own, those seeking accommodation can simply specify a set of requirements and find their wishes realized. Meanwhile, the narrative work performed by the "hybrid hotel" is apparent; it is the kind of anonymous space in which a guilty man might melt away. This chimes with Walter Benjamin's conclusions about detective fiction and the development of the city: if the bustling crowd on the streets is the "newest asylum for outlaws," so, too, is a railway hotel such as this, where few questions are asked by its proprietors (55). Since London forces its inhabitants to turn detective, reading clues about the strangers who surround them, a mystery plot like Edwin Drood can be seen to articulate and formalize a fundamental urban phenomenon.

It is only appropriate that Aldersgate's "hybrid hotel," described by Dickens as a "novel enterprise," appears in Edwin Drood. This is because Drood is, itself, a novel creative enterprise. As an early work of detective fiction, published forty years after Poe's Dupin stories and well before the genre's so-called golden age, it is defined by experimentation rather than its adherence to recognizable formulae. It is also a "hybrid" fiction; its "visitors" have some choice in deciding what sort of story they are reading. (While an overly accommodating and splintering hospitality industry is, for Dickens, a cause for concern, a novel that opens up options is something more to be desired.) Accordingly, there are rented spaces in the novel that do not seem to work as narrative mechanisms - indeed, they are marked by their superfluity to the mystery plot. If characters and spaces are largely functional in the classic mystery - characters are victims, suspects, culprits or detectives; subplots are red herrings; settings are crime scenes; objects are clues - they are only significant insofar as they lead us to what happened. Structurally, a detective story is one of the most purposeful, least compromising forms of narrative there is, but Edwin Drood is a literary space in which genres collide. Comic characters with no obvious relevance to the processes of detection have as much affective force as characters with a clear connection to the crime.

This collision is easily felt in another rented space. When Rosa flees Jasper's clutches and comes to London, Mr. Grewgious finds her a place of refuge on Southampton Street: a "genteel lodging" with Mrs. Billickin, the last new character to spring from Dickens's imagination and onto the page before his death. Mrs. Billickin is distantly related to Grewgious's clerk, and has "once solicited [Grewgious's] influence in the lodger world." With her "faintness" and "overpowering personal candour," she seems to make an entrance from the comic stage (242-43; ch. 22). She is all surface; a legible trope, she resembles Dickens's landladies of old, such as Mrs. 
Raddle, Mrs. MacStinger and Mrs. Crupp, and figures familiar to the contemporary audiences of lodging-house farce, such as John Poole's Mrs. Prattle. ${ }^{6}$ The comic interlude on Southampton Street sits interestingly with the rest of the novel, because it creates a sudden disjunction in tone. Dickens cannot resist building up the humor of the Billickin scenes, pulling Rosa between a somber world of murder and suspicion and an ostensibly self-contained world of farce.

The Billickin is at loggerheads with Miss Twinkleton from their first inauspicious meeting, when one mistakes the other for a piece of luggage. However, there is a great deal taking place behind their humorous antagonism. As Rosa grows tired of the compromises of cohabitation, these lodgings make for a sobering refuge. Living with the Billickin and Miss Twinkleton, she learns how difficult it is to be written into a lodging-house farce without being an active or willing participant, and how ambivalent it feels to get wedged in a farce that never ends. Despite its apparently anarchic energy, farce is, in essence, rigidly structured and even repetitive. Its success depends on timing and pattern rather than on a capacity to surprise. ${ }^{7} \mathrm{At}$ Mrs. Billickin's, this manifests as a deadening daily routine: “As the days crept on and nothing happened, the neighbours began to say that the pretty girl at Billickin's, who looked so wistfully and so much out of the gritty windows of the drawing-room, seemed to be losing her spirits" (254; ch. 22). Dickens, then, suggests that the farce universe can entrap its characters as much as it sets them free. If farce is, for the Billickin, a mode of behavior, for Rosa, it is a claustrophobic experience - one to which she must acclimatize.

London is "gritty" in Rosa's eyes and there is an unmistakable grittiness to the lodgings industry. While Mr. Grewgious draws up the contract, the Billickin rambles about the rattling slates, stain in the ceiling, stinking Mews, tradesmen, servants, provision of coals and disruptive construction works, the physical dangers of being a single woman in the business and the fact she is only a yearly tenant herself, who must sublet rooms to make ends meet. Her insistent possessiveness of her "own exclusive back parlour" - "the back parlior being what she clings to and never parts with" - stresses just how much of her home she is obliged to put to commercial use (243; ch. 22). To "cling to" this space, to "never part" with it, is to appropriate the sentimental language used to describe a strong attachment to a person - not a parlor. This is when it hits home: there is a need to pay attention to comic types, because Dickens heavily implies that the Billickin has been forced into flatness by her circumstances.

At one level, the Billickin interlude brings levity, fulfilling the traditional function of farce during a night at the nineteenth-century theatre: namely, to offer audiences a break before the main event resumed. These scenes are an extension and final reaffirmation of something Dickens first sets out in Oliver Twist: that, though "such changes appear absurd," abrupt

\footnotetext{
${ }^{6}$ The lodging-house farce was an established genre. See, for example, John Poole, Lodgings for Single Gentlemen (1829), Henry Thornton Craven, Done Brown (1845) and JM Morton, Box and Cox (1847).

${ }^{7}$ On the way farce works, see Stuart E. Baker, Georges Feydean and the Aesthetics of Farce (1981) and Jessica Milner Davis, Farce (1978).
} 
dislocations between the "tragic and comic scenes" on stage and page ultimately mirror the "transitions in real life" (134-35; bk. 1, ch. 17). As the Billickin interlude forces us to recalibrate our expectations of Edwin Drood (what kind of novel are we reading?), our disorientation mirrors Rosa's own; over the course of a single day, not to mention a full life, it is usual to feel like we are stepping between stories and genres. But in this movement between mystery and comedy, generic proximity is just a step away from turning into porosity. The lodging-house farce becomes infused with new life. Its predictability ceases to be altogether comforting; instead, it makes us wonder whether we are being lulled into a false sense of security and if something might go wrong. After all, farce, with its slapstick humor, has always been violent; Mrs. Billickin's lodging-house might be the place where characters suddenly fail to repair themselves or stand up again. When might a pratfalling landlady turn into collateral damage?

These questions can only lead so far in an incomplete novel. Because there are no positive answers about what happened to Edwin, the novel encourages us to find significance in details conventionally relegated to the background - it becomes an opportunity to appreciate the complex work an author's use of setting can perform. Here, rented spaces harbor suspects, offer shelter to victims and are prized by detective figures, and though Dickens's final novel is a messy foray into detective fiction, later contributions to the genre only confirm tenancy's narrative centrality still further: Agatha Christie's Evil Under the Sun (1941) and Third Girl (1965) are two examples among many. Finally, while an unfinished murder mystery with no confirmed killer can aggravate its readers, it is important to remember Drood's scope is much broader than this. It is not only concerned with how its protagonist died: it is equally interested in how people live.

\section{The Betrothed's Head}

Mrs. Tope's is one of several underwhelming, slightly sorry lodgings in Edwin Drood. Until he secures his apartments, Datchery stays at the Crozier Hotel; the "orthodox hotel," it is the safe, or only, port of call for visitors. It is "chronically slack" in business, has a "most retiring disposition," and boasts a waiter who is bad at giving directions (202; ch. 18). The Tilted Wagon, where Neville Landless stops for refreshment, is neither prepared nor equipped to receive guests in the morning. These spaces, which shrink into themselves, create a certain mental landscape for the novel. In this section of the essay, I suggest that Edwin Drood provides a series of insights into the psychology of dwelling; for Dickens, the relationship between space and self is mutually informing. When he moves into locations such as Staple Inn, he begins to reflect on the nature of loneliness and the ways in which emotions have a geography.

Before he disappears, Edwin uses an image from the "lodger world" to express his dissatisfaction with the life he is forced to lead. Exasperated at the gossip his engagement with 
Rosa has drawn, he tells Neville, "I wonder no Public House has been set up, with my portrait for the sign of The Betrothed's Head" (72-73; ch. 8). This off-the-cuff remark works at two levels. First, Edwin suggests that his life, constantly subject to intrusion, is like an inn somewhere locals can connect, be entertained and make themselves at home. At the same time, he is drawing attention to his own state of mind. In comparing the betrothed's head - his head to an inn, he reveals it is full of loud and often competing voices, always at risk of tipping out of control.

After Edwin disappears, Neville is apprehended near the Tilted Wagon: a tilt is a canvas cover, but the name is appropriate for a character who has upset the apple cart. When Neville appears again, he is living under a cloud of suspicion in an attic in an Inn of Chancery. In Edwin Drood, Staple Inn becomes a physical space that concentrates Dickens's observations about alienation. In fact, it allows him to weave several strands of argument together; he presents three bachelors who are trying to forge a semblance of a satisfactory domestic life there, which produces many subtly different experiences of solitude. Moving the narrative to this one building, Dickens is able to explore the potentially devastating effect one's dwelling practices might have upon one's mood. Neville's "prisonous" chambers reflect and exacerbate his melancholy: an "air of retreat and solitude [hangs] about the rooms, and about their inhabitant. He is much worn, and so [are] they" (193; ch. 17). Shunted into a garret and corner, he is as isolated, in pure spatial terms, as it is possible to get.

But in the next top-set is an entirely different universe: much like the tidy sentences that describe it, Captain Tartar's "chambers are the neatest, the cleanest, and the best-ordered chambers ever seen under the sun, moon, and stars." If Neville's chambers are compared to a prison, Tartar's are, by contrast, a combination of "seedsman's shop", museum, "dairy," and “admiral's cabin" (236-37; ch. 22). Tartar takes control of his new quarters, creating a cozy and pleasingly personalized space in an unprepossessing pocket of London. In doing so, he displays both the transformative effects of house-pride and his unshakeable confidence in his own identity; he shapes his environment, rather than vice versa. This pair of tenants become an important diptych for Dickens. Their sets are negative images of one another, as if the party-wall were a skewed looking-glass. While Neville's experience is one of corrosive loneliness, Tartar's involves a healthy self-sufficiency and -actualization.

At first, their parallel existences at Staple Inn accentuate the gulf between physical proximity and personal intimacy in the city: to live so near and yet so far to other (seemingly fuller) lives is constantly to confront the possibility of what might have been. If a tenant in chambers is forced, through immediate comparison, to come into partial contact with what he does not have, reading clues about Tartar's life could make Neville's loneliness stronger. Tartar, however, has other ideas. He takes the initiative in Staple Inn. As Neville and Tartar begin to share their spaces, they stand for the redemptive power of cohabitation. Tartar's lucky presence 
acts as a form of salvation for Neville; simultaneously virile and gentle, Tartar may be added to Holly Furneaux's list of male nurses in her study of Dickensian queerness (177-211). He is first introduced perching on Neville's ledge like a "venturesome glazier" (199; ch. 17). A glazier's job is to fit or fix windows and, in so doing, to open lines of vision; as a sympathetic neighbor determined to understand and aid Neville, Tartar achieves precisely this ambition. He decides that meaningful friendship can and should grow out of mere geographical accident. This determination to connect with the stranger next door - and to create a community out of Staple Inn's cells - means that Tartar steps into a detective plot.

Neville, then, offers a portrait of alienation, and Tartar, of independence; the former is a young man who cannot fit in, actively deciding to ostracize himself, and the latter moves to an Inn to teach himself how to be responsible. The shy, elderly Hiram Grewgious, the third bachelor of Staple Inn, completes Dickens's essay on urban solitude. It is in Grewgious that Dickens offers his most sustained exploration of what it means to live alone and to be lonely; one is a spatial practice, the other is its possible psychological corollary, but they are not always as contingent upon one another as it may appear. Grewgious's door is inscribed with the initials of a former tenant, which suggests that he does not have enough force of personality to leave his own impression. His room in Staple Inn, which has "no luxury," is awkwardly divided to accommodate both his public and private characters: it is lined with legal documents and there is a turn-up occasional table in the corner (114; ch. 11). He is thus presented as a man who does not take up space, either literally or socially: a "particularly Angular man," in fact, who "do[es] not fit smoothly into the social circle" (93; ch. 9).

Over the course of the novel, however, he finds himself drawn into the lives of his wards, proving him to be one of Furneaux's "bachelor dads:" figures so ubiquitous in Dickens's fiction that they reveal his urge to "question the assumed moral superiority of the biological family unit and denaturalize the received family pattern of physically related kin" (25). Grewgious makes the most of the tiny community available to him, thanking Edwin and Rosa for their attention when it is he who is "thoughtful and affectionate" (229; ch. 20). When Edwin comes in to ask for advice, he immediately offers him his favorite chair. So begins a scene in which the "angular man" displays his unfussy sense of hospitality at his "snug though faded" fireside; he orders an extravagant dinner from Wood's Hotel in Furnival's Inn and the thought of this "new and relishing sort of gipsy-party" charms Edwin. As Grewgious expresses his appreciation for the company - "you are very kind to join issue with a bachelor in chambers, and take pot-luck" - it is Edwin who "glanc[es] about him," taking notice of his surroundings and, by example, encouraging Dickens's readers to do the same (114-15; ch. 11). Grewgious is well-acquainted with Wood's Hotel; he dines at the restaurant on "three hundred days in the year, at least" (114; ch. 11). This anticipates Roland Barthes' suggestion that "eating alone" is "the essence of solitude" (109). When the "pot-luck" dinner for Edwin and Grewgious arrives, however, it is 
brought by a double-act of waiters who fill the room with activity and joy. For the contemporary critic RH Hutton, the scene with the waiters is a "perfect sketch;" he asks, "did Dickens in his best book ever write a passage of more closely observing humour than that?" (558-59). Given Dickens's intelligent use of the farce mode, and the ways in which its significance modulates in different contexts, this might be pushed further: for Grewgious, so accustomed to an uneventful life, anything out of the ordinary exaggerates itself, appearing heightened or lurid. The solitary Grewgious is well-placed to register the perfect choreography between these waiters, who bounce off one another. Because farce demands teamwork, it has a particular resonance for a lonely man.

Grewgious's loyalty to Wood's Hotel ultimately proves to be important. This hotel, which only exists because of transience, has become a permanent fixture in his universe. Before he establishes Rosa at the Billickin's, Grewgious finds her "the prettiest chamber in Furnival's" (224; ch. 20). Grewgious's solicitude means that he worries how Rosa might react to her new surroundings - "I hope you don't feel very strange indeed, in this strange place," which, in the long term, are "not fit surroundings for a young lady" - but she reassures him of her comfort (229, 242; ch. 20, 22). Dickens describes the extent of Grewgious's "knight-errantry" in moving detail (230; ch. 20). The next day, Rosa's rooms become the site of an emotional reunion after Tartar is granted admittance: as the walls reverberate with Crisparkle and Tartar's shared memories, "the ghost of some departed boy," the young Tartar, "seem[s] to rise, gradually and dimly, in the room" (232; ch. 21). This is also the moment that Tartar and Rosa meet and begin to fall in love. A hotel is, first and foremost, a space that serves a purpose; it exists in order to cater to present need, accommodating those passing through, slipping quickly into obsolescence in any given individual life. Rosa's rooms, however, reactivate meaningful connections from the past and forge enduring connections for the future. Bringing both nostalgia and a sense of promise, this turns into a convivial and hopeful space, with Grewgious's longstanding patronage the catalyst that makes it all possible.

Rosa seems distressed to find that Grewgious "always live[s]" in Staple Inn and "always alone" (225; ch. 20). While other novelists might leave the world between Grewgious's ears uncharted, Dickens does not. He is determined to pay a character like Grewgious the attention that the city itself has denied; Grewgious cannot be "always alone" if there are enough people reading about him. Towards the beginning of the chapter, a question is posed: "Who could have told, by looking at Mr. Grewgious, whether he had ever known ambition or disappointment?" (113; ch. 11). The question has been answered by the end of the chapter, when we learn Grewgious loved Rosa's mother; Dickens assures us "there are such unexplored romantic nooks in the unlikeliest men," implying it is the novelist's role to throw a light into these most mysterious interior spaces (126; ch. 11). Dickens lingers in Grewgious's room after Edwin departs, extending the scene beyond its natural end-point to offer some insight into the 
psychology of loneliness; he uses Grewgious to streamline these abstract meditations. Momentarily animated, the room seems abruptly empty, emptier than usual, in the way rooms often do when visitors leave. After pacing for an hour, tracing the contours of his room and agonizing over other people, Grewgious closes a drawer, then an escritoire, deciding to "shut out the world with the bedclothes" (125; ch. 11). Thus, an instance of energetic, almost performative sociability is followed by a series of images of contraction and containment. The self is extendable and collapsible; extroversion and introversion fluctuate over the course of a few hours; sociability and solitude, Dickens shows, are not permanent states, but more like shifting moods. Grewgious's enjoyment of one is followed by a strong desire for the other; they can be equally comforting and equally exhausting. In this study of how one bachelor handles his loneliness, Dickens suggests that living alone is not numbing. He also turns away from the idea that loneliness is taboo, a pathology to be resisted at all costs - something Olivia Laing has recently deconstructed in The Lonely City (2016), using twentieth-century New York as a casestudy. For Laing, the determining factors of loneliness combine and intersect; in Edwin Drood, Dickens accepts it is a complex emotional condition that, in its blending of the psychological and spatial, should be scrutinized.

Ultimately, Staple Inn becomes a crucible for questions of solitude and sociability. It is just one of many Inns of Court and Chancery that seem to stand for a potent form of urban loneliness: in his reminiscences, Percy Fitzgerald recalls "how Boz disliked poor Gray's Inn! [...] He must have felt these terrors in his own lonely rooms at Furnival's." Fitzgerald goes on to talk about Edwin Drood explicitly:

It is always a subject for wondering that he did not draw that wonderful old Inn Clifford's, still standing - gloomy and dreary enough to be the scene of murders and plots and general violence. It, and not Staples' Inn [sic], ought to have figured in "Edwin Drood". How picturesque it is [...] here one could well fancy Jasper having some garret to which he might have decoyed his victim (2: 157-58).

As he retrospectively tries to improve the novel, Fitzgerald declares that Dickens should have given the Inns an overt narrative function: he thinks Clifford's should have been a crime scene. This "gloomy and dreary" Inn seems more fitting as a backdrop for "general violence" than Staple Inn. In ruing Dickens's missed opportunity, though, Fitzgerald ultimately misses the point: a quiet sort of violence is already taking place here. These scenes reveal how cruel cities can be, and Dickens meticulously charts the small adjustments Londoners make in order to bring themselves into contact with the world.

\section{Beginning in Boxes}


For Grewgious, to look for a "furnished lodging" is to "set out in quest of adventures," but it is also to tread familiar territory (242; ch. 22). Grewgious is one of many characters who deal in rented spaces professionally; others include Mrs. Billickin, Mrs. Tope and Deputy. Space begins to feel like a commodity that is parceled out by experts in itinerance. The ground in Dickens's universe shifts between people's feet; the power of these agents highlights the essential passivity of everyone else, pitched from place to place. In drawing attention to Grewgious the rentreceiver, Sapsea the estate agent and Tartar the landowner, Dickens demonstrates the ways in which space is co-opted to a variety of political ends, including the formulation of conceptions of nationhood. Space, for Dickens, is not neutral; it channels power.

Given his occupation, it is unsurprising that Grewgious is confused when he hears about Helena and Neville: "What is the Landlesses?", he asks; "an estate? A villa? A farm?" (117; ch. 11). Grewgious lives in London's legal quarter because he is a "professional Receiver of rents" (93; ch. 9). Having failed at "coy conveyancing," a branch of the law that involves the drawing up and transferring of property rights, he becomes an agent to "two rich estates" (113; ch. 11). Grewgious's ineptitude for conveyancing has interesting implications. At first, it seems curious that Dickens should make such a point of his career-change. If we read Edwin Drood alongside the legal writings of Chandos Wren Hoskyns, however, this aspect of Grewgious's character begins to open up and offers a broader political context for the novel. In Edwin Drood, Dickens describes a social and economic structure that gains much of its meaning from land.

Dickens first met Hoskyns in 1858, when Hoskyns presided over a dinner held in his honor. Hoskyns, a Warwickshire landowner, had a fledgling career in the law before becoming an MP around the time of Drood's publication. He had a deep interest in agriculture - more specifically, in the ways in which English land laws and tenure needed urgent reform. In a letter thanking Hoskyns for his speech, Dickens declares: "I cannot tell you with what cordial pleasure I have received your letter and reread your excellent book" (Letters 8: 722). The reference is to Hoskyns's Talpa, or, The Chronicles of a Clay Farm, then into its fourth edition after an original run in the Agricultural Gazette. Talpa, Hoskyns announces, "break[s] and baffle[s] every rule of literary composition;" it is part diary and part episodic narrative, written with whimsical humor, using this "livelier tongue" to make its practical observations accessible (233-34). Hoskyns's raison d'etre was to popularize esoteric and provincial knowledge and this seems to inform Dickens's work in Edwin Drood, albeit in oblique ways. In 1859, Dickens expressed further interest in Hoskyns's writings: "I look forward to the receipt of the promised sheets, eagerly." He then offered a perspective of his own: "I believe that the whole philosophy of the subject lies in those remarkable words you use, touching the locked-up social evils underlying the whole fabric of the land in this country, and only unknown and uncured, because the land is its own legislator" (Letters 9: 60). Drood can be read as Dickens's attempt to work this idea out and take a last stand against red tape. 
Hoskyns's arguments and recommendations remain consistent between Talpa and two later treatises, published as Dickens put Edwin Drood together: Land in England, Land in Ireland, and Land in Other Lands (1869), which revises material previously written for periodicals, and The Land-Laws of England (1870). Hoskyns makes a bold central claim: "If I were asked what one thing is left for an Englishman to complain of, I should at once answer in one brief expression, his Land Laws." Hoskyns's treatises chart centuries of legal history and explains how the roots of the current system are to be found in feudal culture; indeed, this system "remains unchallenged by public notice and intelligence" precisely because its origins lie so far back and has become normalized by the time the nineteenth century comes around (Land in England 2-3). He pushes for three major changes to land law: namely, to the outdated processes of conveyance (the transfer of land through purchase), entail (by which an historic landowner's decree about the inheritance of his estate governs its inheritance in all subsequent generations) and primogeniture (by which land passes to the eldest son). According to Hoskyns, these three elements have come together particularly insidiously in England, culminating in the current evils of tenure. In a "virtual confiscation of the soil by the very rich," most of the nation's land, and its attendant wealth and power, remain in the hands of a few families. This supremacy of large estates favors the large tenant-farmer in turn, to the detriment of small tenants and agricultural laborers (Land in England 30). As workers are pushed into the towns, they fill "miserable cellars and garrets," weaving country and city together (Land in England 36). Hoskyns draws attention to the fundamental strangeness of tenancy as a concept. Unlike "the parental, filial, or fraternal instinct," "no appeal lies to any innate sense [...] in aid of the tie" between owner and occupier: it is not a natural relationship and involves a simultaneous "antagonism of interest" and "mutuality of object' (Land-Laws 121-22, 129).

Ultimately, Hoskyns argues that real property should function in the same way as personal property: it should be alienable. After all, farming is already implicated in what the Marxist philosopher Henri Lefebvre would call the "production of space;" "had the agricultural fact been kept in view that a Seed-bed [...] is as strictly an artificial production of labour as any that is wrought by man's hands upon Nature's materials," Hoskyns suggests, "the political economist might perhaps have had a lighter task" (Land-Laws 97). At the end of Talpa, he offers a clarion call:

Prolix conveyances, and complicated settlements, operate as a charge upon the land, an impediment to its exchange, a reduction of its value, a drain upon the resources of the Owner, a secret injury to the Tenant and the Labourer [...] Free the soil from the pestilent tyranny of parchment $[\ldots]$ and more will be accomplished for its increase in commercial value, its preference as a field for investment, its promotion of skill and invention, its contribution to the employment and the happiness of the greatest number, than all the mere physical improvement that could be enumerated or detailed, were every "Clay Farm" in merry England to supply its "Chronicle" (244-45). 
This is a utopian vision, built around choice, the movement of capital and faith in Britain's progress. For Hoskyns, eager to "take Adam Smith in [his] hand," obstructing the free trade in land prevents the state from flourishing (Land in England 54).

When he disparages "prolix conveyances" and the "pestilent tyranny of parchment," Hoskyns provides Dickens with a skeleton for Grewgious. The procedures in place for transferring land, Hoskyns repeatedly emphasizes, are complex and obscure, which deters potential buyers and sellers, "paralys[es] commerce" and "amount[s] almost to a national scandal" (Land in England 17). The "sheepskin 'Deeds"” on which transfer depends are written in "language requiring sometimes the translation, sometimes the deciphering, but always the interpretation, of an expert:" namely, a conveyancer (Land in England 6; Land-Laws 114). Hoskyns is careful not to blame the conveyancer for the difficulties of transfer - "he has only to obey Instructions" - but he does point out that certain members of the profession are loath to promote reform, given their pecuniary interest in the present system (Land in England 14). When Dickens uproots Grewgious from this profession and sets him down in another, he suggests Grewgious is too straightforward to either master "coy conveyancing's" arcana or revel in its jargon. Grewgious becomes a focal point for Dickens's ideas about the land system and the "locked-up social evils" it simultaneously crystallizes and preserves.

Grewgious does not leave this world entirely. Now a rent-receiver, he acknowledges to Rosa that his job still makes him unpopular, but he is not the kind of wily steward that might be familiar to the nineteenth-century audiences of melodrama: for example, he has little in common with Douglas Jerrold's villains in The Rent Day (1832), where tenants live under threat of eviction. ${ }^{8}$ In guaranteeing a landowner's rental income, receivers ensured the smooth running of both estate and state; after all, landowners had the vote and had both a literal and political stake in the soil. Melodramas emphasized the unfairness of this power structure and painted individual stewards as the source of "social evils:" they were reactionary enforcers of the status quo, working on the side of the landlord at the expense of the tenant. This is patently not true of Grewgious. His academic interest in property renders him more sensitive than most to the spaces around him. Given the responsibility of allocating spaces to people and people to spaces - for him, housing Rosa comfortably is the ultimate act of care - he determines the trajectory of their lives. He receives rents from a Norfolk farmer, presumably a large tenant on an equally large estate. (Hoskyns mentions the two- or three-thousand acre farms to be found in Norfolk and Lincolnshire). Melodrama does not fit this narrative of receiver and mega-tenant, and so the novel has to offer an alternative. Instead of browbeating the farmer, Grewgious accepts gifts of turkeys and the informal custody of his son, Bazzard. Bazzard comes to Grewgious with his father's rent and discloses his ambition to be a playwright, and Grewgious employs him so that he can pursue these aspirations. Agents and middle-men such as Grewgious ensure other lives are

\footnotetext{
${ }^{8}$ On this play, see Juliet John, Dickens's Villains (2001), 65.
} 
kept in order - they facilitate major decisions and events, are go-betweens in relationships, look after things over which they have no inherent claim - essentially, a vicarious existence.

Dickens is careful to show how a person responsible for the way other people dwell, might dwell himself. With his boxes full of other people's domestic arrangements, which tidily line his room, he lives by proxy. The boxes are well-ordered because:

The apprehension of dying suddenly, and leaving one fact or one figure with any incompleteness or obscurity attaching to it, would have stretched Mr. Grewgious stone dead any day. The largest fidelity to a trust was the life-blood of the man. There are sorts of life-blood that course more quickly, more gaily, more attractively; but there is no better sort in circulation (114; ch. 11).

Hoskyns is adamant that feudalism has no place in the present age; if tenure once "kept society together in a sort of chivalrous interdependence, which was better than independent barbarism," it is not required for the functioning of the modern state (Land in England 11). Nonetheless, stewardship is Grewgious's vocation or "life-blood." It stands for an ethical imperative to take on a series of "trusts" and to hold himself accountable to those trusts. This imperative diffuses until it becomes a core aspect of his character: his scrupulous guardianship of Rosa and Edwin and his indulgence of Bazzard are, at heart, other "fidelit[ies] to a trust." In Grewgious, Dickens takes us back to the first principles of stewardship and implies that this might offer a pattern for a healthy civic life.

Despite the differences in their characters - one protector, one persecutor - Grewgious and Thomas Sapsea are shadowy versions of each other. Sapsea is an auctioneer and estate agent, and these professions are engraved onto his wife's tombstone. He "likes to pass the churchyard with a swelling air of proprietorship, and to encourage in his breast a sort of benignant-landlord feeling, in that he has been bountiful towards that meritorious tenant, Mrs. Sapsea" (126; ch. 12). He filters both marriage and death through the language of ownership and paternalism, but he is no "benignant" landlord, taking care of the tenants on his estate. Instead, he is parasitic, makes a living out of the property of others and "has even (in selling landed property) tried the experiment of slightly intoning in his pulpit" (35; ch. 4). Claiming this rhetorical power, he is appointed Mayor of Cloisterham. Placing an estate agent and auctioneer in a position of influence seems to bring out the worst of each profession. Sapsea's work, puffing up land and goods, has made him an expert in bluster and bullying; he makes direct gains from the atomization, dissolution, uprooting and instability of households; he believes price to be the only index of an object's worth; he equates what one owns with who they are. On murder, he has one thing to say - "to take the life of a fellow creature is to take something that [doesn't] belong to you" equating it with an act of property theft (172; ch. 15). As he doles summary justice on Neville, he represents terrible local power. 
Only Tartar can claim national power through his ownership of freehold, and, having benefited from invidious systems of inheritance, nonetheless becomes a model of how to wield this authority well. While his neighbor, Neville, is literally landless, Tartar is lately landed, leaving his work as a sailor to come into his legacy. This newly-minted gentleman is a fairytale character, whose pot-plants and runners bring life to the rooftops of central London, but this is not just a whim; his gardening fulfils a serious function, because he is re-investing in English soil after many years at sea. This erstwhile "tartar" has forgotten what it means to have roots, and so he makes a decision to take chambers and start an urban garden. His resolution stems from his inheritance of his uncle's estate:

I chose this place, because, having served last in a little Corvette, I knew I should feel more at home where I had a constant opportunity of knocking my head against the ceiling. Besides: it would never do for a man who had been aboard ship from his boyhood to turn luxurious all at once. Besides, again: having been accustomed to a very short allowance of land all my life, I thought I'd feel my way to the command of a landed estate, by beginning in boxes (200; ch. 17).

He takes this opportunity to practice land management. Tartar's rented rooms represent his estate in miniature; each flowerpot is filled with the English mud his tenants will till. Presumably, he will be "benignant" in his new position, aware of his positive capacity to influence - both locally, as squire, and nationally, as voter. One of Hoskyns's criticisms of the law is its entrenched sense of deferral; the obsession with "the Unborn," via primogeniture and entail, means that a current landlord is merely the custodian of his plot until the next heir arrives. For Hoskyns, this defeats "the purpose that the soil was made for [...] It was meant to be cultivated like a garden by somebody, not tied up, like a lettuce, for somebody Else's future enjoyment" (Land in England 14). Tartar has already shown himself to be a hands-on cultivator. According to liberal hints, he and Rosa may eventually have an heir to think about, but his concerns seem grounded in the present.

Thus, Tartar embraces "beginning in boxes." He feels "at home" in Staple Inn and falls in love in Wood's Hotel. Dickens indicates he will be a successful landlord because he sees his time in chambers as formative: it is a significant rite of passage rather than a purgatory to be endured and left behind. In a nation where power works through space in overt ways and where land is routinely instrumentalized for economic gain and political clout, this is how the owner of an estate can redeem himself. But there may be one more layer to Dickens's argument: Hoskyns's treatises respond directly to the Irish Question and the problems caused by absentee landlords. These English Protestant aristocrats lived in England, rented farms to Irish Catholic tenants and drained the country of its natural wealth. For Hoskyns, it is impossible for the government to begin offering viable solutions to the Irish Question when the land system in England is still so dysfunctional. Two months before the first number of Drood appeared, Parliament passed the ineffective Landlord and Tenant (Ireland) Act. Dickens does not mention Ireland in the novel, 
but Tartar, the returning landlord, casts a striking figure against a backdrop of real-life absentees. If exploitative systems of ownership and tenure shape the nation, they might also determine the nation's place in the world.

Dickens's last novel is essentially hospitable. It is partly a murder mystery, partly a psychological study of the characters left behind; partly an innovative foray into new genres, partly a homage to farce; partly a survival manual for city living; partly a serious meditation on gender, political power and the capitalist forces that touch the domestic sphere. Like the "hybrid hotel" in Aldersgate, Edwin Drood can be anything we want it to be. Are we, Drood's readers, also Droods tenants? Perhaps - but we will be found burrowing into the corners of this "venerable, architectural, and inconvenient" novel long past our check-out time.

\section{Works Cited}

Anon. "Board and Residence." The Times 1 August 1870 p. 13.

Armstrong, Isobel. "Theories of Space and the Nineteenth-Century Novel." 19: Interdisciplinary Studies in the Long Nineteenth Century 17 (2003): 1-21.

Bachelard, Gaston. The Poetics of Space. Trans. Maria Jolas. Boston: Beacon Press, 1994.

Baker, Stuart E. Georges Feydeau and the Aesthetics of Farce. Ann Arbor: UMI Research Press, 1981.

Barthes, Roland. How to Live Together: Novelistic Simulations of Some Everyday Spaces. Trans. Kate Briggs. New York: Columbia University Press, 2013.

Benjamin, Walter. Charles Baudelaire: A Lyric Poet in the Era of High Capitalism. Trans. Harry Zohn. London: NLB, 1973.

Chase, Karen and Michael Levenson. The Spectacle of Intimacy: A Public Life for the Victorian Family. Princeton: Princeton University Press, 2000.

Craven, Henry Thornton. Done Brown. London: Duncombe, 1845.

Crook, Tom. "Accommodating the Outcast: Common Lodging Houses and the Limits of Urban Governance in Victorian and Edwardian London." Urban History 35.3 (2002): 414-36.

Davis, Jessica Milner. Farce. London: Methuen, 1978.

Dickens, Charles. The Letters of Charles Dickens. Ed. Madeline House, Graham Storey, et al. 12 vols. Oxford: Clarendon, 1965-2002.

—. The Mystery of Edwin Drood. Ed. David Paroissien. London: Penguin, 2002.

—. Oliver Twist. Ed. Philip Horne. London: Penguin, 2003.

—. "On Duty With Inspector Field." The Dent Uniform Edition of Dickens' Journalism. Ed. Michael Slater and John Drew. 4 vols. London: J. M. Dent, 1994-2000. 2: 356-69.

Fitzgerald, Percy. The Life of Charles Dickens as Revealed in His Writings. 2 vols. London: Chatto and Windus, 1905.

Furneaux, Holly. Queer Dickens: Erotics, Families, Masculinities. Oxford: Oxford University Press, 2009.

Hamon, Philippe. "What is a Description?" French Literary Theory Today: A Reader. Ed. Tzvetan Todorov. Trans. R. Carter. Cambridge: Cambridge University Press, 1982. 147-78.

Hoskyns, Chandos Wren. Land in England, Land in Ireland, and Land in Other Lands. London: Longman and Co., 1869.

- The Land-Laws of England. System of Land Tenure in V arious Countries: A Series of Essays Published Under the Sanction of the Cobden Club. $2^{\text {nd }}$ edn. London: Macmillan and Co., 1870. 95-147.

- Talpa: Or the Chronicles of a Clay Farm. An Agricultural Fragment. $4^{\text {th }}$ edn. London: Longman, Brown, Green, Longmans and Roberts: 1857.

Hutton, RH. [Unsigned Review.] Spectator 1 October 1870 pp.1176-75. The Critical Heritage. Ed. Philip Collins. London: Routledge, 1986. 557-59.

John, Juliet. Dickens's Villains: Melodrama, Character, Popular Culture. Oxford: Oxford University Press, 2001.

Laing, Olivia. The Lonely City: Adventures in the Art of Being Alone. Edinburgh: Canongate, 2016.

Lefebvre, Henri. The Production of Space. Trans. Donald Nicholson-Smith. Oxford: Blackwell, 1991. 
Marcus, Sharon. Apartment Stories: City and Home in Nineteenth-Century Paris and London. Berkeley and London: University of California Press, 1999.

Moretti, Franco. Atlas of the European Novel, 1800-1900. London: Verso, 2007.

[Morley, Henry]. "Houses in Flats." Household Words 24 March 1855 pp. 182-86.

Morton, John Maddison. Box and Cox. London: Duncombe, 1847.

Poole, John. Lodgings for Single Gentlemen. London: Duncombe, 1829.

Tally Jr., Robert T. Spatiality. London: Routledge, 2013.

Thompson, FML. English Landed Society in the Nineteenth Century. London: Routledge and Kegan Paul, 1963.

Tuan, Yi-Fu. Topophilia: A Study of Environmental Perception, Attitudes, and Values. Englewood Cliffs: PrenticeHall, 1974.

Waters, Catherine. Dickens and the Politics of the Family. Cambridge: Cambridge University Press, 1997. 